\title{
Accounting Conservatism and the Company’s Performance: the Moderating Effect of the Ownership Structure
}

\section{Affes $\mathrm{H}$ and Sardouk $\mathrm{H}^{\star}$}

Faculty of Economics and Management of Sfax, University of Sfax, Tunisia

\begin{abstract}
The purpose of this article is to highlight the moderating effect of a central mechanism of governance, namely, the ownership structure in the relationship between accounting conservatism and the enterprise's performance using a sample of French companies listed on the Paris stock exchange. Previous studies have investigated the impact of corporate governance on the level of accounting conservatism. Our objective is to study the effect on the relationship between the level of accounting conservatism and performance of a central governance mechanism, namely, the ownership structure. We examine the concentration effect of institutional, wage and property of such a mechanism on the relationship between accounting conservatism and the accounting company's performance which is measured by the return on equity in 60 French listed companies belonging to the SBF 120 index in all the period 2007-2012 of enterprises. Else more most of the results support the moderating effect of such a mechanism that has been ignored or overlooked by previous work.
\end{abstract}

Keywords: Ownership structure; Moderating effect; Accounting conservatism; Accounting performance

\section{Introduction}

The impact issue of the accounting information quality on performance has been the subject of several theoretical and empirical controversies. Several new empirical approaches have emerged gradually in order to make attempts at answers to the observed theoretical and methodological limitations [1-3].

The 2000's crisis outbreak led to a questioning of the accounting information credibility and of its relevance for investors. It was followed by multiple reforms with the main objective is to strengthen the security of the transactions. The origin of this crisis is found in the previous economic and financial literature which has always praised the benefits of the market, its free functioning and its ability to recover its state of equilibrium with spontaneity. However, confidence in the market self-regulatory mechanisms is shaking when crises occur and we begin to think about the governmental or legislative action to restore the imbalance born of the inefficient operation or imperfect markets [4]. This crisis has particularly highlighted the failure of governance models.

Following this crisis, several codes were established to ensure quality financial information and serve as a basis for the mitigation of the agency conflicts between the companies and the various stakeholders. The adoption of new regulations for governance promotes the development of a new wave of research focusing exclusively on the study of the contribution of the Sarbanes Oxley accounting Act.

Further research connects accounting to the law and estimates that the adoption of new regulations may lead to the improvement of the accounting result quality [5-10]. The position long defended in the context of previous research relies on the idea that the rule of law implementation will induce a change in corporate finance and accounting system.

According to the OCDE report (1997, p. 22), organizations use corporate governance to meet the information and incentive problems in large enterprises. Corporate governance is also a proper combination of the investors' legal protection and ownership concentration [11]. She establishes rules that ensure the information transparency [12].
Our study analyzed the nature of the effect of governance mechanisms such as the ownership structure on the relationship between accounting conservatism and company's performance. We try to identify the moderating effect of this mechanism.

In this sense, we seek to answer the following question: What is the contribution of ownership structure to the relationship between accounting conservatism and the company's performance which is measured by the return on equity?

Several authors showed that the relevance of the accounting results depend on the effectiveness of the governance mechanisms in place [13-15]. Taking account of the moderating effect of ownership as a mechanism of governance structure is, in our opinion, an enrichment for the existing literature.

The remainder of the paper is structured as follows: we begin with a brief survey of the empirical literature. The description of the sample data and variables as well as the presentation and discusses of our empirical findings will be figured in a next part.

\section{Literature Review and Hypothesis Development}

The literature review identifies the accounting result as an important indicator of performance measurement. The finding of the aggressiveness of the accounts and the decrease of the response factors of the benefits demonstrated by several authors pushed researchers to wonder about the relevance of the accounting figures [16,17].

Regarding the information quality in the financial statements, any business has an interest in ensuring the quality of its information

*Corresponding author: Hadia Sardouk, $\mathrm{PhD}$ researcher in accounting sciences, Faculty of Economics and Management of Sfax, University of Sfax, Tunisia, Tel: 21674242951; E-mail: hsardouk@ymail.com

Received April 21, 2016; Accepted May 05, 2016; Published May 12, 2016

Citation: Affes H, Sardouk H (2016) Accounting Conservatism and the Company's Performance: the Moderating Effect of the Ownership Structure. J Bus Fin Aff 5: 188. doi:10.4172/2167-0234.1000188

Copyright: ( $\odot 2016$ Affes $\mathrm{H}$, et al. This is an open-access article distributed under the terms of the Creative Commons Attribution License, which permits unrestricted use, distribution, and reproduction in any medium, provided the original author and source are credited. 
disclosure to avoid losing its partners' confidence. Although several studies have attributed the weak association between the results and returns to the investors' irrationality, many others insisted on the importance of confidence in the determination of the level of the information relevance for the financial investor. The investors' rationality is supposed to be reflected in their ability to detect any opportunistic behavior on the part of the agent and translate this into their trading decisions $[13,14,18]$.

Actually, these investors sometimes considered irrational seem to take into account other factors relating to the company which provide them with information on the reliability and credibility of the accounting information communicated to them. These factors relate in most cases to corporate governance mechanisms that give an idea about the accuracy of the information that is communicated to them, such as ownership structure.

Given the importance of this regulatory authority, it would be interesting to analyze its impact on the relationship between the quality of the accounting information represented by the level of the accounting conservatism and the company's performance. In this sense, the communicated information may be influenced by dilution, concentration or some types of shareholdings.

The previous literature review broadly supports the significant influence of the shareholding on the practices of the information disclosure by companies [19]. Shleifer et al. Dsemsetz, Agrawal et al. affirm that capital concentration promotes the executives' control by the shareholders [11,20-25]. Charléty says that majority shareholders find it advantageous to take control over the leaders to protect the realized profits [26]. For Mtanios and Paquerot, these shareholders have substantial advantages over their minority counterparts in case of a conflict with the company's management [27]. Moreover, they can exercise their discretion at the expense of the minority shareholders' interests, as challenged by Shleifer and Vishny, and subsequently become unfavorable to publish financial information [11]. In this sense, better financial publication will be the one that protects the minority shareholders from the controlling shareholders' actions [28]. According to Ben Ali, ownership structure in France has gone through important developments [29]. Shleifer and Vishny affirm that a good governance system is an appropriate combination of legal investors' protection and ownership structure concentration [11]. It reduces the agency costs and creates a disciplinary effect which requires less financial information. Therefore, better financial information helps protect the minority shareholders from the controlling shareholders' actions [28]. According to Shleifer, ownership concentration is an efficient governance mechanism that leads to a company's high performance [30]. The adoption of management incentives significantly affects the accounting conservatism and the information quality [31]. Chen et al. confirm that companies with concentrated participation may be less incented to improve the quality of the financial statements [32]. According to Srivastava and Tse, the financial statements reflect the accounting conservatism [33]. Everything designed to protect the interests regarding those of the users' management as well as the level and trend of conservatism are relevant to the users of financial statements. Therefore, ownership concentration impacts the conservatism accountant-performance relationship.

So capital concentration is a useful monitoring tool for leaders, but its influence on the quality of the provided information remains to be studied. The examination of the literature shows that shareholding nature may also affect the quality of the disseminated information.
Foreign institutional investors as well are demanding in terms of information quality. To attract them, the company must ensure highquality information. Generally, they claim a level of information that brings up the risks incurred by the firm and its critical success factors [34]. Since they have invested in the firm, these foreign investors have all the power to influence the managerial decision making [35]. It is beneficial for to be vigilant and effectively control the managers [36]. Institutional shareholders may also influence the votes $[37,38]$. Healy et al. consider them to be the most demanding agents in terms of regular financial information published in due time [39]. They are more demanding in terms of information disclosure and their presence can have a direct effect on the agency costs [40]. Following the development of the growing number of institutional investors in the financial market, the institutional ownership structure in France has encountered several major changes [28]. This is in line with Agrawal and Medelker who argue that this type of shareholders has an influential partner for the company. Institutional shareholders have a greater capacity in information processing [41]. They have special skills which enable them to analyze the company's accounts, its development prospects and management quality [42]. Therefore, institutional investors are an executive control mechanism for the managers [43]. The latter's asset leads them to become active participants in the governance systems. Most of previous studies decided in favor of the positive impact of the institutional property on the performance and the establishment of a low aspect of accounting conservatism within companies held by several institutional investors.

Similarly, $\mathrm{Ng}$ et al. advanced that the strong structure of the state property is associated with a strong performance [44]. Estrin and Perotin confirms that in nations with weak financial systems, public ownership may be more advantageous than private property, insofar as the State may have greater access to information and a great power to monitor and sanction the performance of managers [45]. Sun et al. on examining a sample of 680 listed Chinese companies during the 1994/1997 period, concluded that the State property structure has a non-linear either inverted U-shaped or concave relationship with the stock market performance [46]. Studies of Wei and Varela and Wei et al. on a sample of Chinese enterprises, simultaneously conclude a convex relationship between State ownership structure and market performance $[47,48]$. Conducting a study on a sample of 276 Chinese companies over the 1999/2002 period, Wei found neither an inverted U-shaped nor a U-shaped relationship [49]. Nevertheless, he found a nonlinear relationship in which he observed negative effects on performance when the State owns more than $50 \%$ of the property share. When the State property is below $50 \%$, there is no negative effect on performance. The author came to the conclusion that the absence of State ownership structure has a positive effect on the company's performance. According to D'Souza and Megginson, Boubakri and Cosset, Eckel, Eckel and Singal and Magginson, Nash and Randenborgh, large efficiency improvements are reported within the companies in which the Government does not hold the majority control [50-52]. For Claesson et al. the company is more likely to maintain high levels of employment if the State keeps a majority stake [53]. In a study on 435 European firms, Thomsen and Pedersen those companies lose value when the Government is the largest owner [54]. Under $\mathrm{Ng}$ et al. the strong structure of State property is associated with a strong performance [44]. The regulation hypothesis considers that regulatory authorities can face political pressure and public criticism [55]. To reduce the political costs and protect the investors' interests, these authorities rather prefer the accounting prudence. Therefore, a higher level of the investors' protection is supposed to lead to a higher 
Citation: Affes H, Sardouk H (2016) Accounting Conservatism and the Company's Performance: the Moderating Effect of the Ownership Structure. J Bus Fin Aff 5: 188. doi:10.4172/2167-0234.1000188

Page 3 of 8

level of conservatism [56]. As a result, it can be said that the issue of the relationship between the Government property and performance has not been resolved in literature.

In the same vein, some researchers found the role played by the pay property, given that employees may pursue objectives other than those of the maximization the company's performance [57,58]. Similarly, Boycko et al. testified that employees are unlikely to support the efforts of maximizing the value [59]. However, others argued that pay property can have positive effects on performance through incentives and the creation of a cooperative atmosphere that increase confidence and information sharing. Hence, the results identified by earlier studies did not bring up clear results. The empirical evidence on the impact of the employee shareholding on performance and accounting conservatism remain inconclusive. Some studies decided in favor of the latter, while for others, the effect is negligible.

Based on the arguments cited above, we will assume that ownership structure and its characteristics have a moderator effect on the relationship between accounting conservatism and the enterprise's performance. Hence, the foregoing discussion suggests the following hypothesis:

H: Ownership structure has a moderator effect on the relationship between accounting conservatism and the enterprise's performance.

\section{Data and Sample Description}

\section{Study sample}

Our study covers the period 2007-2012 and focuses on 60 French companies belonging to the SBF 120 index. Our choice of the study period is explained by the evolution of accounting conservatism level following the adoption of standards IFRS in 2005, particularly in the French context. Thus, our study focuses on a sample of 60 French firms observed over a period of 6 years. This will lead us to estimate panel data regression models that take into account the individual effects of companies and periods studied. In panel data, the model that takes into account the presence of heteroskedasticity and autocorrelation is the model Feasible Generalized Least Squares (FGLS) which explains our choice about using this search method. We have eliminated the companies for which data was missing, those belonging to sectors presenting a particular functioning such as banks and those with accounting practices requiring a specific treatment. The final sample consists of 360 firm- years' observations (Table 1).

Although the basics 'Thomson Financial', 'Diane', 'Worldscope' and 'Dafsaliens' are the sources of our accounting data, we referred to annual reports to collect data of characteristics of the ownership structure manually extracted on websites.

\section{Research model and measurement}

To study the moderating effect of ownership structure in the relationship between accounting conservatism and enterprise's

\begin{tabular}{|c|c|c|}
\hline Activity area & Firm & Percentage of total \\
\hline Services & 12 & 20 \\
\hline Petroleum & 7 & 11.6 \\
\hline Industries & 15 & 25 \\
\hline Technology & 8 & 13.4 \\
\hline Health & 2 & 3.3 \\
\hline Consumer goods & 16 & 26.7 \\
\hline Total & 60 & 100 \\
\hline & Table 1: Sample selection. \\
\hline
\end{tabular}

performances, the following model will be tested:

$$
\begin{aligned}
& \text { PERF }_{i t}=\beta_{0}+\beta_{1}(C-S C O R E)_{i t-1}+\sum \beta(1+h) X_{i t-1}+\sum \beta(5+h)(C-\text { Score })_{i t-1} * X_{i t-1} \\
& +\beta_{10} \text { TAILLE }_{i t-1}+\beta_{11} \text { ENDET }_{i t-1}+\beta_{12} \text { Contentieux }_{i t-1}+\beta_{13} \text { Vérification }_{i t-1}+\varepsilon_{i t}
\end{aligned}
$$

The indices $i$ and $t$ correspond, respectively to the company and the year (2007-2012)

PERF: enterprise's performance; C-Score: Accounting Conservatism; X: variables linked to the characteristics of ownership structure.

Enterprise's performance, PERF: The choice of performance measurement is complex and depends among other evaluation criteria [60]. Several authors have opted for the consideration of several measures simultaneously [61,62]. The review of existing empirical studies that examined the performance of companies reveals the dominant place occupied by accounting measures [63-66]. In this sense our concern to compare our results with those of the majority of the research works, led us to retain accounting nature indicator.

ROE (Return on Equity): denotes the ratios: Net profit/equity.

Accounting conservatism: C-Score: According to Khan, M., and Watts R. L., C-Score reflects the change in accounting conservatism between companies [67]. The authors fit the model of Basu [68] and found that conservatism is a linear function of the ratio market-tobook, the size and the leverage such as:

C- SCORE it $=\lambda 0+\lambda 1[$ SIZE it $]+\lambda 2[(\mathrm{M} / \mathrm{B})$ it $]+\lambda 3[\mathrm{LEV}$ it $]+\varepsilon$ it

Where SIZE: is the natural log of equity market value.

M/B: Market value/book value.

LEV: is defined as a long-term and short-term debt deflated by equity market value.

The model of Basu adjusted by Khan, M., and RL Watts and Ahmed, A., and Duellman S., is written as follows [67-69]:

$\mathrm{Xi}, \mathrm{t} / \mathrm{Pi}, \mathrm{t}-1=\beta 0+\beta 1(\mathrm{Dit})+\beta 2($ Rit $)+\beta 3$ (Rit Dit) $+\varepsilon \mathrm{i}, \mathrm{t}$

To substitute $ß 3$ with C-Score in equation 1, lead to the following equation:

$\mathrm{Xi}, \mathrm{t} / \mathrm{Pi}, \mathrm{t}-1=\beta 0+\beta 1(\mathrm{D} \quad \mathrm{i}, \mathrm{t})+\beta 2 \quad(\mathrm{Ri}, \mathrm{t})+\mathrm{Dit} \quad \mathrm{R} \quad \mathrm{i}, \mathrm{t} \quad(\lambda 0+\lambda 1 \quad$ (SIZE) $i, t+\lambda 2(\mathrm{MB}) i, t+\lambda 3($ LEVi,t) $)+\varepsilon i, t$

To estimate the conservatism level, we begin by estimating $\lambda \mathrm{i}, \mathrm{i}=0$ to 3 in equation (3), then we introduce the parameters estimated in equation (1) to obtain the conservatism level on each company and for each year.

Ownership structure variables: X: According to Lobo G. and J. Zhou, companies are on average more conservative in their financial reports after the Sarbanes-Oxley Act. For Bessieux-Ollier C [70], French and German companies have higher levels of conservatism that the US companies. This can be explained by the difference at the level of the property structure. Indeed, French ownership structure is more concentrated than its American counterpart. In this regard, we can affirm that the agency problems lead to call for accounting caution as a regulator of the managers' opportunistic behavior. For the purpose of a more thorough, study of the characteristics of ownership structure and their effect on the relationship between enterprises' performances and accounting conservatism becomes essential (Table 2). 
Citation: Affes H, Sardouk H (2016) Accounting Conservatism and the Company's Performance: the Moderating Effect of the Ownership Structure. J Bus Fin Aff 5: 188. doi:10.4172/2167-0234.1000188

Page 4 of 8

\begin{tabular}{|c|c|c|c|}
\hline \multirow[t]{2}{*}{ Variable } & Abreviation & Measures & \multirow[t]{2}{*}{ Bibliographic references } \\
\hline & \multicolumn{2}{|c|}{ Measure of performance } & \\
\hline \multirow[t]{2}{*}{ Performance } & PERF & ROE=Net results /shareholders ' equity & Xu and Wang (1999), Jia et al. (2005) Omran [77] \\
\hline & Conservatism variable & & \\
\hline Accounting cnservatism & C-score & C-SCORE i,t $=\lambda 0+\lambda 1($ SIZE i,t) $+\lambda 2((M / B) i, t)+\lambda 3($ LEV i,t) & $\begin{array}{l}\text { Basu [68] Khan and Watts [67] Ahmed and } \\
\text { Duellman [69] }\end{array}$ \\
\hline Ratio market to Book & M/B & Market value/book value & Khan and Watts [67] \\
\hline Size & SIZE & Log of the market value of the shareholders' equity & Khan and Watts [67] \\
\hline \multirow[t]{2}{*}{ Leverage effect } & LEV & Total debts of the shareholders' equity & Khan and Watts [67] \\
\hline & Ownership variables & & \\
\hline Ownership concentration & CONC & $\%$ of the capital retained by institutionals & $\begin{array}{l}\text { Chen et al. (2005); Thomson and } \\
\text { Pedersen(2000); Ng et al. (2009) }\end{array}$ \\
\hline Institutional participation & ACT_INST & $\%$ of the capital directly or indirectly held by the government & Wei, Xie and Zhang [48] \\
\hline State ownership & STATE & $\%$ of the capital held by the employees & Wei and Varela [47] \\
\hline \multirow[t]{2}{*}{ Employees' participation } & ACT_SAL & Turnover log & $\begin{array}{l}\text { Sesil and Al (2001); Blair and Al (2000); Dondi } \\
\text { (1992) }\end{array}$ \\
\hline & Control variables & & \\
\hline Company's size & TAILLE & Debt ratio=total debts/ total equity & $\begin{array}{l}\text { Boubakri et al. [51]; Mak and Kusandi (2002); } \\
\text { Villalonga (2000) }\end{array}$ \\
\hline Leverage effect & ENDET & $\begin{array}{l}\text { Binary variable }=1 \text { if the company is technological and } 0 \\
\text { otherwise }\end{array}$ & $\mathrm{Ng}$ et al. [44]; Sun et al. [46] \\
\hline Litigations & Contentieux & $\begin{array}{l}\text { Binary variable } 1 \text { if the company is controlled by a large board } \\
\text { and } 0 \text { otherwise }\end{array}$ & Field et al. [45] \\
\hline Auditing & Vérification & $\begin{array}{l}\text { Binary variable } 1 \text { if the company belong to CAC } 40 \text { and } 0 \\
\text { otherwise }\end{array}$ & Watts [55] \\
\hline
\end{tabular}

Table 2: Summary of variables definitions and measurements.

\begin{tabular}{|c|c|c|c|c|c|c|c|c|c|}
\hline & Mean & Median & Max & Min & Std. Dev. & Skewness & Kurtosis & Jarque-Bera & Probability \\
\hline PERF & 10,705 & 10,097 & 143,244 & $-100,459$ & 15,675 & 1,428 & 28,555 & 9863,516 & 0,000 \\
\hline C_SCORE & 0,133 & 0,126 & 0,362 & $-0,162$ & 0,100 & $-0,015$ & 2,758 & 0,885 & 0,642 \\
\hline ACT_INST & 50,037 & 49,905 & 96,000 & 0,481 & 25,727 & $-0,022$ & 1,838 & 20,166 & 0,000 \\
\hline ACT_SAL & 3,257 & 1,600 & 37,000 & 0,000 & 5,138 & 3,216 & 15,218 & 2843,661 & 0,000 \\
\hline CONC & 27,180 & 20,700 & 84,480 & 0,437 & 21,563 & 0,985 & 3,094 & 58,076 & 0,000 \\
\hline ENDET & 0,319 & 0,235 & 7,605 & 0,005 & 0,512 & 10,463 & 136,154 & 271005,300 & 0,000 \\
\hline LEV & 0,319 & 0,235 & 7,605 & 0,005 & 0,512 & 10,463 & 136,154 & 271005,300 & 0,000 \\
\hline $\mathrm{M} / \mathrm{B}$ & 1,833 & 1,457 & 28,423 & 0,000 & 1,950 & 7,914 & 100,055 & 144246,600 & 0,000 \\
\hline ROE & 0,026 & 0,024 & 0,202 & 0,000 & 0,023 & 2,763 & 20,581 & 5066,105 & 0,000 \\
\hline SIZE & 9,489 & 9,646 & 13,544 & 4,257 & 1,507 & $-0,079$ & 3,202 & 0,987 & 0,611 \\
\hline STATE & 4,399 & 0,000 & 84,800 & 0,000 & 14,356 & 4,054 & 20,192 & 5389,457 & 0,000 \\
\hline TAILLE & 9,489 & 9,646 & 13,544 & 4,257 & 1,507 & $-0,079$ & 3,202 & 0,987 & 0,611 \\
\hline X/P & 2,837 & 2,608 & 9,986 & $-9,426$ & 2,899 & $-0,416$ & 4,760 & 56,489 & 0,000 \\
\hline
\end{tabular}

Table 3: Variables' descriptive statistics.

\section{Results and Discussion}

In what follows we will discuss the obtained results about the moderator effect of the ownership structure in the relationship between conservatism and accounting performance of listed companies.

\section{Descriptive analysis}

We will report, in the following study, the descriptive statistics belonging to the entirety of variables investigated in our study. First of all, we will present descriptive statistics over the period: 2007-2012 such as; Mean, Median, Maximum, Minimum, Std. Dev Skewness, Kurtosis and Jarque-Bera (Table 3).

Then, we will present the descriptive statistics belonging to dichotomous variables as following Table 4 .

We note that the average concentration of the property attributable to the first shareholder is $27.18 \%$. The average participation of institutional investors, employees and the state is, respectively, of the order of $50.037 \%, 3.26 \%$ and $4.4 \%$. Accordingly, there is not a significant

\begin{tabular}{|c|c|c|c|}
\hline \multicolumn{4}{|c|}{ Dichotomous variables } \\
\hline & Modalities & effectifs & Frequency (\%) \\
\hline Verification & 0 & 180 & 50 \\
& 1 & 180 & 50 \\
\hline Contentieux & 0 & 324 & 90 \\
& 1 & 36 & 10 \\
\hline
\end{tabular}

Table 4: Dichotomous variables.

disparity in the intensity of the quality of accounting information measured by the degree of accounting conservatism (the standard deviation of this variable c-score is relatively small: 0.1 ). Indeed, we do not notice a remarkable difference between the minimum (-0.162) and the maximum (0.362). This could reflect the level of accounting performance for firms in our sample (10,705\%).

\section{Correlation analysis}

The problem of multicollinearity between explanatory variables affects the treatment of any linear regression. This problem occur when variables are highly correlated or perfectly together, causing instability 
of the estimated coefficients and a sharp increase in their standard deviations. To circumvent the multicollinearity problem, we will study bi-varied correlations between explanatory variables (Table 5).

The examination of the correlation matrix shows that all coefficients are below 0.9 limit from which we have a serious problems of multicolinearity. From this table, we can also noticed that all our explanatory variables have a high VIF value below 5 , extreme limit suggested by Gujarati and Kennedy [71,72]. These results make us conclude that we have not a serious problem of multi-collinearity.

\section{Regression analysis}

In what follows, we will study a sample of 60 French listed companies over several years, leading to estimate a regression model on panel data. The particular nature of panel data leads us to follow some econometric steps. First of all, we tested variables heteroscedasticity using the Breusch-Pagan test. This test revealed a significant Fisher F. Then, to test the error autocorrelation, we conducted the Wooldrigde autocorrelation test within individuals [73]. The results confirm the presence of a serial autocorrelation. To sum up, it can be concluded that there are heteroscedasticity and autocorrelation problems. In panel data, the model that accounts for the presence of autocorrelation and hétérioscédasticité is the FGLS model. The following table presents the FGLS estimates of the various regression models which include the variables related to ownership structure. Models 5 and 8 of the following table test separately the interaction effect of each variable depending on the level of accounting conservatism it has on company performance. The model 1 of Table 5 include simultaneously all the variables related to ownership structure and their interactions with the degree of conservatism (Table 6).

Our object is to verify the existence of a moderator effect of the ownership structure and to test our hypothesis that ownership structure has a moderator effect on the relationship between accounting conservatism and the Company's performance. As we have already noted our test will be execute by FGLS model.

The examination of Table 5 helps us to identify the following points. Regarding property concentration the $\mathrm{C}$-Score ${ }^{\star} \mathrm{CONC}$ interaction term is positive and significant. This result confirms the positive moderating effect of ownership concentration on the relationship between accounting conservatism and corporate performance. Such a result suggests that concentrated ownership is a factor that favors the commitment to accounting conservatism practices which create value and improve company's performance.

Regarding the moderating effect of the investors' participation of institutional in the capital on the relationship between accounting conservatism and corporate performance, our achieved results shows that it negative and weakly significant at (10\%) at Model 1 but not significant in model 7 . These results made us respond to the effect of institutional ownership in determining the relationship between accounting conservatism and performance. This thesis joins Schadewitz and Blevins in their study of Finnish companies, who support the existence of an inverse relationship between the institutional shareholding concentration and the disclosed information [74].

Regarding the moderating effect of State ownership on the relationship between conservatism and business performance the interaction term C-score ${ }^{\star}$ STATE is not significant. The accounting regulation can thus affect either negative or positive about the quality of information dissemination. Barret, in his study of French companies, said that information dissemination is of low quality due to the presence of the 1957 accounting plan [75]. This means that no additional information is suggested beside the one requested by the latter [76].

Regarding the pay property, the study of the interaction effect of the C-score ${ }^{\star}$ ACT_SAL term on the company's performance shows that this effect is not significant. This result bears the prediction backed by Boycko et al. and Omran that employees show a poor monitoring and are unlikely to support value maximization efforts $[59,77]$.

We can finally point out that our achieved results appear to be consistent with the studies conducted by $\mathrm{Ng}$ et al. Bushman and Piotroski, Ben Ali, Chen et al. Shleifer et al. who have demonstrates the positive impact of ownership structure on the performance and the establishment of a low aspect of accounting conservatism within companies [11,29,30,32,44,56].

Our results demonstrates that a significant relationship exist between accounting conservatism ownership structure and enterprise's performance. Moreover, ownership structure has been considered by many authors, such as Boyko et al. Hawrylyshyn and Gettigan, as a major obstacle to the development of the company since the workers can persue reasons other than maximizing objectives $[57,58]$.

With regard the control variables, the variables litigations "contentieux" coefficient appear to be significant. This finding can well be explained by the fact that the presence of large audit firm results in a more timely information disclosure broadcast [78]. This finding has been supported by Shukeri et al. who have noted that the annual report completion period is highly associated with the auditor type [79].

\section{Conclusion}

Through this paper, we tried to present the moderating effect of ownership structure of the relationship between accounting conservatism and company's performance with respect to a sample

\begin{tabular}{|c|c|c|c|c|c|c|c|c|c|c|c|}
\hline & Perf & C-Score & Conc & State & Act-Inst & Act-Sal & Verif & Cont & Taille & Endett & Vif \\
\hline Perf & 1 & & & & & & & & & & 3.33 \\
\hline C-Score & -0.069 & 1 & & & & & & & & & 4.01 \\
\hline Conc & 0.153 & -0.555 & 1 & & & & & & & & 2.11 \\
\hline State & -0.443 & -0.358 & 0.362 & 1 & & & & & & & 2.66 \\
\hline Act-Inst & -0.068 & 0.33 & -0.501 & -0.185 & 1 & & & & & & 2.01 \\
\hline Act-Sal & -0.038 & -0.104 & -0.192 & 0.031 & 0.11 & 1 & & & & & 1.03 \\
\hline Verif & -0.059 & 0.378 & -0.405 & 0.115 & 0.409 & 0.047 & 1 & & & & 3.54 \\
\hline Cont & -0.223 & -0.056 & -0.095 & 0.015 & -0.03 & -0.009 & -0.111 & 1 & & & 4.04 \\
\hline Taille & -0.099 & 0.239 & -0.125 & 0.296 & 0.199 & 0.156 & 0.634 & -0.331 & 1 & & 1.56 \\
\hline Endett & -0.026 & -0.047 & -0.157 & -0.027 & 0.095 & 0.005 & -0.166 & 0.106 & -0.212 & 1 & 1.77 \\
\hline
\end{tabular}


Citation: Affes H, Sardouk H (2016) Accounting Conservatism and the Company's Performance: the Moderating Effect of the Ownership Structure. J Bus Fin Aff 5: 188. doi:10.4172/2167-0234.1000188

Page 6 of 8

\begin{tabular}{|c|c|c|c|c|c|}
\hline $\begin{array}{l}\text { Cross-sectional time-series } \\
\text { Coefficients: Panel Feasible } \\
\text { Number of observations }=360\end{array}$ & ast Square & eroskedasti & sectional & & \\
\hline Variable dépendante : PERF & & & & & \\
\hline Variables Indépendantes & Modèle 8 & Modèle 5 & Modèle 6 & Modèle 7 & Modèle 8 \\
\hline & $\begin{array}{l}\text { Coeff. } \\
\text { (z-stat) }\end{array}$ & $\begin{array}{l}\text { Coeff. } \\
\text { (z-stat) }\end{array}$ & $\begin{array}{l}\text { Coeff. } \\
\text { (z-stat) }\end{array}$ & $\begin{array}{l}\text { Coeff. } \\
\text { (z-stat) }\end{array}$ & $\begin{array}{l}\text { Coeff. } \\
\text { (z-stat) }\end{array}$ \\
\hline Constante & $\begin{array}{l}21,175^{* *} \\
(1,999)\end{array}$ & $\begin{array}{c}22,457^{* \cdots} \\
(2,762)\end{array}$ & $\begin{array}{l}22,591^{\cdots *} \\
(2,6668)\end{array}$ & $\begin{array}{l}25,263^{* *} \\
(2,9536)\end{array}$ & $\begin{array}{l}23,106 * * \\
(2,7796)\end{array}$ \\
\hline C-score & $\begin{array}{l}20,038^{+* *} \\
(2,0163)\end{array}$ & $\begin{array}{c}4,5635 \\
(0,2692)\end{array}$ & $\begin{array}{c}10,43^{* *} \\
(2,0376)\end{array}$ & $\begin{array}{c}6,442 * * \\
(3,0324)\end{array}$ & $\begin{array}{c}6,0245^{*} \\
(1,9886)\end{array}$ \\
\hline CONC & $\begin{array}{l}0.12276 \\
(1,0842)\end{array}$ & $\begin{array}{l}0,0351^{* *} \\
(3,4843)\end{array}$ & & & \\
\hline C-score ${ }^{*}$ CONC & $\begin{array}{c}0,4755^{*} \\
(1,9513)\end{array}$ & $\begin{array}{l}0,2214^{* *} \\
(4,4096)\end{array}$ & & & \\
\hline STATE & $\begin{array}{c}-0,175008 \\
(-1,524)\end{array}$ & & $\begin{array}{l}-0,0744 \\
(-1,9437)\end{array}$ & & \\
\hline C-score* STATE & $\begin{array}{c}-0,7467 \\
(-0,60406)\end{array}$ & & $\begin{array}{c}-0,5986 \\
(-0,75105)\end{array}$ & & \\
\hline ACT_INST & $\begin{array}{l}-0,0538^{*+*} \\
(-3,7907)\end{array}$ & & & $\begin{array}{c}-0,0613^{\cdots *} \\
(-5,23)\end{array}$ & \\
\hline C-score*ACT_INST & $\begin{array}{l}-0,00451^{*} \\
(-1,9448)\end{array}$ & & & $\begin{array}{c}-0,0007 \\
(-0,3777)\end{array}$ & \\
\hline ACT_SAL & $\begin{array}{l}0,055312 \\
(0,16162)\end{array}$ & & & & $\begin{array}{c}0,016 \\
(0,0516)\end{array}$ \\
\hline C-score*ACT_SAL & $\begin{array}{c}1,0528 \\
(0,33361)\end{array}$ & & & & $\begin{array}{c}0,344 \\
(0,1212)\end{array}$ \\
\hline Verification & $\begin{array}{c}0,08811 \\
(0,02932)\end{array}$ & $\begin{array}{c}0,0119 \\
(0,00439)\end{array}$ & $\begin{array}{c}-0,714 \\
(-0,2666)\end{array}$ & $\begin{array}{c}-0,4993 \\
(-0,1799)\end{array}$ & $\begin{array}{c}-0,8548 \\
(-0,3162)\end{array}$ \\
\hline Contentieux & $\begin{array}{l}-9,3624^{* *} \\
(-2,4269)\end{array}$ & $\begin{array}{l}-9,331^{* * *} \\
(-2,637)\end{array}$ & $\begin{array}{c}-9,349^{* * *} \\
(-2,5679)\end{array}$ & $\begin{array}{l}-9,492+* \\
(-2,6479)\end{array}$ & $\begin{array}{l}-9,574 \\
(-2,6604)\end{array}$ \\
\hline Taille & $\begin{array}{l}-1,42319 \\
(-1,2584)\end{array}$ & $\begin{array}{c}-1,357 \\
(-1,5115)\end{array}$ & $\begin{array}{l}-1,0756 \\
(-1,1499)\end{array}$ & $\begin{array}{l}-1,27433 \\
(-1,4343)\end{array}$ & $\begin{array}{l}-1,2203 \\
(-1,347)\end{array}$ \\
\hline Endet & $\begin{array}{l}-0,24288 \\
(-0,15673)\end{array}$ & $\begin{array}{c}-0,057 \\
(-0,039)\end{array}$ & $\begin{array}{c}-0,0637 \\
(-0,0435)\end{array}$ & $\begin{array}{l}-0,11955 \\
(-0,0786)\end{array}$ & $\begin{array}{c}-0,106 \\
(-0,072)\end{array}$ \\
\hline $\begin{array}{l}\text { Breusch-Pagan Lagrangian Mu } \\
\text { Test for Random Effects }\end{array}$ & & & & & \\
\hline $\begin{array}{l}\text { Chi2 } \\
\text { Prob>chi2 }\end{array}$ & $\begin{array}{c}52,75 \\
(0,000)\end{array}$ & $\begin{array}{c}60,97 \\
(0,000)\end{array}$ & $\begin{array}{c}74,62 \\
(0,000)\end{array}$ & $\begin{array}{l}73,70 \\
(0,000)\end{array}$ & $\begin{array}{c}75,28 \\
(0,000)\end{array}$ \\
\hline $\begin{array}{l}\text { Breusch-Pagan Test for } \\
\text { Heteroskedasticity }\end{array}$ & & & & & \\
\hline $\begin{array}{l}\text { F-statistic } \\
\text { Prob }>F\end{array}$ & $\begin{array}{l}1104,35 \\
(0,000)\end{array}$ & $\begin{array}{l}731,54 \\
(0,000)\end{array}$ & $\begin{array}{l}573,64 \\
(0,000)\end{array}$ & $\begin{array}{l}588,31 \\
(0,000)\end{array}$ & $\begin{array}{l}404,403 \\
(0,000)\end{array}$ \\
\hline Wald Test for Heteroskedasticit & & & & & \\
\hline $\begin{array}{l}\text { Wald chi2 } \\
\text { Prob>chi2 }\end{array}$ & $\begin{array}{l}304,35 \\
(0,000)\end{array}$ & $\begin{array}{c}33,77 \\
(0,000)\end{array}$ & $\begin{array}{c}41,02 \\
(0,000)\end{array}$ & $\begin{array}{c}37,72 \\
(0,000)\end{array}$ & $\begin{array}{c}44,02 \\
(0,000)\end{array}$ \\
\hline Wooldridge Test for Autocorrele & & & & & \\
\hline $\begin{array}{l}\text { F-statistic } \\
\text { Prob }>F\end{array}$ & $\begin{array}{c}70,9553 \\
(0,00000)\end{array}$ & $\begin{array}{c}15,3849 \\
(0,00305)\end{array}$ & $\begin{array}{l}14,9873 \\
(0,0005)\end{array}$ & $\begin{array}{c}13,5617 \\
(0,00022)\end{array}$ & $\begin{array}{c}12,71 \\
(0,000267)\end{array}$ \\
\hline
\end{tabular}

Table 6: Results of the FGLS estimates for the analysis of the moderating effects of ownership structure on the relationship between the accounting information quality and the company's performance.

made up of 60 French companies observed over the period 20072012. The objective of this work is twin. We have apprehended the effect of accounting conservatism on the performance of the company and identify the moderating effect of the ownership structure on the relationship between the accounting conservatism and the performance of the company. The practical implication of our study consists in studying the effect of the interaction of the ownership structure and the accounting conservatism on the company's performance. In this sense our moderating variable namely the ownership structure modulates the direction and the force of the effect of accounting conservatism on the company's performance. Identify the moderating effect of the ownership structure is of a great importance since moderation increases the significance of the relationship between accounting conservatism and company performance. Yet the ignorance of such effect may lead to the conclusion about the likely impact of the low level of accounting conservatism on the company's performance. At the end of our empirical analysis, some conclusions were in contradiction with what the theories had advanced. This divergence has forced us to find a theoretical and empirical explanation for these results.

Our study of the effect of ownership structure on the relationship between the level of accounting conservatism and the company's performance shows that the ownership concentration is positive and significant. As suggested by Shleifer, ownership concentration promotes the practice of accounting conservatism and consequently generates the improvement of company's performance [30]. However, State and pay ownership has an insignificant effect. This makes us 
Citation: Affes H, Sardouk H (2016) Accounting Conservatism and the Company's Performance: the Moderating Effect of the Ownership Structure. J Bus Fin Aff 5: 188. doi:10.4172/2167-0234.1000188

Page 7 of 8

conclude that this type of property has no effect as to the improvement of performance through the moderating effects. Regarding institutional property, the released results suggest that discriminate against the commitment of conservatism accounting practices. To such results are added that of Salehi et al. which shows the negative effect of this type of property on the relationship between the level of accounting conservatism and performance [80].

Just like any other research, the present elaborated study involves certain limitations. Our results confirm the contribution of the ownership structure of the relationship between accounting conservatism and performance in the financial statements published by French companies during the period 2007-2012. It will be interesting to study a sample of firms from several countries to highlight other factors outside the company, such as the legal environment, the country's economic policy and the culture of the actors who are not studied in this research.

\section{References}

1. Mauldin E, Richetermeyer S (2004) An analysis of ERP Annual Report Disclosure. International Journal of Accounting Information Systems 5: 395416.

2. Lang M, Lundholm R (1993) Cross-Sectional determinants of analysts rating of corporate disclosures. Journal of Accounting Research pp: 246-271.

3. Kasznik R, Johnson MF (2001) The impact of securities litigation reform on the disclosure of forward looking information by high technology firms. Journal of Accounting Research 39: 297-327.

4. Deffains B, Guigou JD (2002) Droit, gouvernement d'entreprise et marchés de capitaux. Revue d'Economie Politique 112: 791-862.

5. Cohen DA, Dey A, Lys TZ (2005) Trends in earnings management and informativeness of earnings announcements in the Pre- and Post-Sarbanes Oxley Periods. Northwestern University, Illinois.

6. Cohen DA, Dey A, Lys TZ (2008) Real and accrual-based earnings management in the pre- and post- Sarbanes-Oxley periods. The Accounting Review 83: 757-787.

7. Begley J, Cheng Q, Gao Y (2008) Changes in Analysts' Information Environment Following the Sarbanes-Oxley Act and the Global Settlement. University of British Columbia, University of British Columbia.

8. Chang KC, Sun W (2009) Message Passing for Hybrid Bayesian Networks Representation, Propagation, and Integration. IEEE Transactions on Aerospace and Electronic Systems 45: 1525-1537.

9. Haidan L, Pincus M, Rego SO (2008) Market reaction to events surrounding the Sarbanes-Oxley Act of 2002. Journal of Law and Economics pp: 1-39.

10. Bartov, Cohen (2009) The 'Numbers Game' in the Pre- and Post-SarbanesOxley Eras. Journal of Accounting, Auditing \& Finance 24: 505-534.

11. Shleifer A, Vishny R (1997) A survey of corporate governance. The Journal of Finance 2: 737-783.

12. Beaufort R (2006) FSM Library: description de I'API: Rapport technique. Rue Pierre et Marie Curie, Belgique.

13. Warfield TD, Wilda JJ, Wild KL (1995) Managerial ownership, accounting choices, and informativeness of earnings. Journal of Accounting and Economics 20: 61-91.

14. Gabrielsen RH, Braathen A, Dehls J, Roberts D (2002) Tectonic lineaments of Norway. Norwegian Journal of Geology 82: 153-174.

15. Jung K, Kwon SY (2001) Ownership structure and earnings informativeness: Evidence from Korea. The International Journal of Accounting 37: 301-325.

16. Collins D, Kothari SP (1989) An analysis of the cross-sectional and intertempora determinants of earnings response coefficients. Journal of Accounting and Economics 11: 143-181.

17. Francis J, Schipper K (1999) Have financial statements lost their relevance. Journal of Accounting Research 37: 319-352.

18. Fan JPH, Wong TJ (2002) Corporate ownership structure and the informativeness of accounting earnings in East Asia. Journal of Accounting and Economics 33: 401-425.

19. Adhikari A, Tondkar RH (1992) Environmental factors influencing accounting disclosure requirements of global stock exchanges. Journal of International Financial Management and Accounting 4: 75-105.

20. Porta RL, Lopez-de-Silanes F, Shleifer A, Vishny RW (1998) Law and finance. Journal of Political Economy pp: 1113-1155

21. Laporta R, Lopez-de-Silanes F, Shleifer A (1999) Corporate ownership around the world. Journal of Finance pp: 471-517.

22. Laporta R, Lopez-de-Silanes F, Shleifer A, Vishny RW (2000) Investor protection and corporate governance. Journal of Financial Economics 58: 3-27.

23. Demsetz $H$ (1983) The structure of ownership and the theory of the firm. The Journal of Law and Economics 26: 375-390.

24. Agrawel A, Mandelker GN (1990) Large shareholders and the monitoring of managers: The case of antitakeover charter amendments. Journal of Financial and Quantitative Analysis 25: 143-161.

25. Faccio R, Grano M, Colucci S, Villa A, Giannelli G, et al. (2002) Localization and possible role of two different alpha $v$ beta 3 integrin conformations in resting and resorbing osteoclasts. J Cell Sci 115: 2919-2929.

26. Charléty (2001) Fiscalité des stocks options, innovation et gouvernement des entreprises. Economie et Statistique 4: 3-37.

27. Mtanios R, Paquerot M (1999) Structure de propriété et sous performance des firmes: une étude empirique sur le marché au comptant le règlement mensuel et le second marché. Finance Contrôle Stratégie 2: 157-180.

28. Ali CB (2007) Qualité de publication financière et gouvernance: cas du SBF 120. Acte de colloque du 28 ème congrès de l'AFC, Poitiers.

29. Ali CB (2002) Disclosure quality and ownership structure: evidence from the French Stock Market. Actes du 4ième colloque sur le gouvernement de l'entreprise, Faculté Warocqué, Mons, Belgique pp: 1-23

30. Shleifer A (1997) Government in Transition. European Economic Review 41 $385-410$.

31. Ball LJ, Lucas EJ, Phillips P (2005) Eye movements and reasoning: Evidence for relevance effects and rationalization processes in deontic selection tasks. Lancaster University, UK pp: 196-201.

32. Chen C (2001) Prognostic modeling studies of the Keweenaw current in Lake Superior. Part I: formation and evolution. J Phys Oceanogr 31: 379-395.

33. Srivastava A, Sunder S, Tse S (2009) Timely Loss Recognition and the Early Termination of Unprofitable Projects. China Journal of Accounting Research 8: 147-167.

34. Bushee BJ, Noe CF (2000) Disclosure Quality, Institutional Investors, and Stock Return Volatility. Journal of accounting Research 38: 203-207.

35. Carleton WT, Nelson JM, Weisbach MS (1998) The Influence of Institutions on Corporate Governance through Private Negociations: Evidence from TIAACREF. Journal of Finance 53: 1335-1362.

36. Vigliano MH (2007) Contrôle du conseil d'administration et rémunération des dirigeants: réplication de la recherche de Boyd (1994) au contexte français XVlème conférence Internationale de Management Stratégique (AIMS), Montréal le 6-9 juin 2007

37. Alexandre H, Paquerot M (2000) Efficacité des structures de contrôle et enracinement des dirigeants. Finance Contrôle Stratégie 3: 5-29.

38. Boyd BK (1994) Board control and CEO compensation. Strategic Management Journal 15: 335-344

39. Healy PM, Hutton AP, Palepu KG (1999) Stock performance and intermediation changes surrounding increases in disclosure. Contemporary Accounting Research 16: 485-520

40. Lapointe $P(2000)$ Structure de propriété, investisseurs institutionnels et performance de l'entreprise. Revue Gestion 25: 92-96.

41. Agrawel A, Mandelker GN (1992) Shark repellents and the role of institutional investors in corporate governance. Managerial and decisions economics 13 $15-22$

42. Zghal R (2005) La question des ressources humaines en Tunisie. dans A 
Citation: Affes H, Sardouk H (2016) Accounting Conservatism and the Company's Performance: the Moderating Effect of the Ownership Structure. J Bus Fin Aff 5: 188. doi:10.4172/2167-0234.1000188

Scouarnec et Z. Yanet (dir.), Perspectives sur la GRH au Maghreb, AlgérieMaroc-Tunisie, Vuibert 165-174.

43. Shleifer A, Vishny RW (1986) Large shareholders and corporate control. The Journal of political Economy 94: 461-488.

44. Ng A, Yuceb A, Chen E (2009) Determinants of state equity ownership, and its effect on value/performance: China's privatized firms. Pacific-Basin Finance Journal 17: 413-443.

45. Estrin S, Perotin V (1991) Does Ownership Always Matter. International Journal of Industrial Organization 9: 55-72.

46. Sun Z, Yang W, Siebenmorgen T, Stelwagen A, Cnossen A, et al. (2002) Thermo mechanical transitions of rice kernels. Cereal Chem 79: 349-353.

47. Wei Z, Varela O (2003) State equity ownership and firm market performance: evidence from China's newly privatized firms. Global Finance Journal 14: 6582.

48. Wei Z, Xie F, Zhang S (2005) Ownership Structure and Firm Value in China's Privatized Firms: 1991-2001. Journal of Financial and Quantitative Analysis 40: 87-108.

49. Wei G (2007) Ownership structure, corporate governance and company performance in China. Asia Pacific Business Review 13: 519-545.

50. D'Souza J, Megginson WL (1999) The Financial and Operating Performance of Newly Privatized Firms in the 1990s. Journal of Finance 54: 1397-1438.

51. Boubakri N, Cosset JC (1998) The Financial and Operating Performance of Newly- Privatized Firms: Evidence from Developing Countries. Journal of Finance 53: 1081-1110.

52. Eckel C, Eckel D, Singal V (1999) Privatization and efficiency: Industry effects of the sale of British Airways. Journal of Financial Economics 43: 275-298.

53. Claessens S, Detragiache E, Kanbur R, Wickham P (1997) HIPC's Debt: review of the Issues. Journal of African Economies 6: 231-254.

54. Thomsen S, Pedersen T (2000) Ownership structure and economic performance in the largest European companies. Strategic Management Journal 21: 689-705.

55. Watts RL (2003) Conservatism in accounting, Part I: Explanations and Implications. Accounting Horizons 17: 207-221.

56. Bushman RM, Piotroski JD (2006) Financial Reporting Incentives for Conservative Accounting: The Influence of Legal and Political Institutions. Journal of Accounting and Economics 42: 107-148.

57. Boycko M, Vishny RW, Shleifer A (1995) Privatizing Russia. MIT Press, Cambridge.

58. Havrylyshyn O, McGettigan D (1999) Privatization in transition countries: a sampling of the literature. IMF Working Paper.

59. Boycko M, Shleifer A, Vishny RW (1996) A Theory of Privatization. The Economic Journal 106: 309-319.

60. Charreaux G (1997) L'entreprise publique estelle nécessairement mois efficace? Revue Française de Gestion pp: 38-56.

61. Séverin (2000) Structure de propriété et performance des firmes: analyse du cas français. Université de Lille 2, GERME-ESA.
62. Kali R, Sarkar J (2005) Diversification, propping and monitoring: Business groups, firm performance and the Indian economic transition. Indira Gandhi Institute of Development Research, Mumbai, India

63. Megginson WL, Nash RC, Randenborgh MV (1994) The Financial and Operating Performance of Newly Privatized Firms: An International Empirical Analysis. Journal of Finance 49: 403-452.

64. Alexandre H, Charreaux G (2004) L'efficacité des privatisations françaises: une vision dynamique à travers la théorie de la gouvernance. Revue économique 55: 791- 821.

65. Aussenegg W, Jelic R (2007) The Operating Performance of Newly Privatized Firms in Central European Transition Economies. European Financial Management 13: 853-879.

66. Kang C (2009) Privatization and production efficiency in Taiwan's telecommunications industry. Telecommunications Policy 33: 495-505.

67. Khan M, Watts RL (2009) Estimation and validation of a firm-Year Measure of Conservatism. Journal of Accounting \& Economics 48: 132-150.

68. Basu S (1997) The conservatism principle and the asymmetric timeliness of earnings. Journal of Accounting and Economics 24: 3-37.

69. Ahmed A, Duellman S (2013) Managerial overconfidence and accounting conservatism. Journal of Accounting Research 51: 1-30.

70. Bessieux-Ollier C, Lacroix M, Walliser E (2006) Le capital humain: approche comptable versus approche managériale. Revue Internationale sur le Travail et la Société 4: 25-57.

71. Gujarati D (1995) Basic Econometrics. McGraw-Hill International Edition, New York.

72. Kennedy P (1998) A guide to econometrics. Blackwell, Oxford.

73. Wooldridge JM (2002) Econometric Analysis of Cross Section and Panel Data MIT Press, Cambridge, MA.

74. Schadewitz HJ, Blevins DR (1998) Major determinants of interim disclosures in an emerging market. American Business Review 16: 41-55.

75. Barret (1975) Motoneuron dendrites: role in synaptic integration. Fed Proc 34 1398-1407.

76. Michailesco C (1998) Contribution à l'étude des déterminants de la qualité de l'information comptable diffusée par les entreprises françaises. Thèses de Sciences de Gestion, Université Paris Dauphine, France.

77. Omran M (2009) Post-privatization corporate governance and firm performance: The role of private ownership concentration, identity and board composition. Journal of Comparative Economics 37: 658-673.

78. Clatworthy MA, Peel DA, Pope PF (2011) Are analysts' loss functions asymmetric? Journal of Forecasting 31: 736-756.

79. Shukeri SN, Shin OW, Shaari MS (2012) Does board of directors; characteristics affect firm performance: Evidence from Malaysian public listed companies. International Business Research 5: 120-128.

80. Salehi M, Talebnia G, Ghorbani B (2011) A Study of the Relationship between Liquidity and Stock Returns of Companies Listed in Tehran Stock Exchange. World Appl Sci J 12: 1403-1408. 